\title{
The age of aesthetic perception of the environment - concept in architecture and historical data
}

\author{
Eugenijus Staniunas, Vilnius Gediminas Technical University, Lithuania
}

\begin{abstract}
The object of the research whose findings are presented in the article is on the contact line between two life "elements" - the popular contemporary architectural culture and data of contemporary historical knowledge. In the analysis, it is attempted to disclose how the notion "Aesthetics" is viewed from both sides of that line, seeking to ascertain whether contemporary architectural society sees the duration of an aesthetic attitude of the human being towards its environment in the same way how this make history data.
\end{abstract}

Keywords: view, aesthetics, architecture, historical data

\section{Introduction}

Why the historical knowledge of age of an aesthetic attitude towards environment could be important for the contemporary architectural culture? Different pictures of the age of aesthetical attitude towards environment support different paradigms - different modes of architectural life.

If man's "aesthetic needs" emerged along with human being, then we should think that they are one of the perpetual elements of his nature. If aesthetic relationship between people and their surroundings is an inevitable characteristic of human nature, then the essential knowledge about this phenomenon is got - all further discussions about "Aesthetics", all the attempts to cast a deeper insight into its essence are, practically, is nothing but a waste of time. The only really important task that survives for the architectural activity in this case is to concentrate on environment and to satisfy this human requirement. The popular definition of function of architectural activity is correct.

But if the aesthetical attitude towards environment has not appeared together with the men, it means it is not the eternal element of human nature. Would it be logical to approve that architecture is activity that fulfills the aesthetic needs, if people did not use it for that purpose for a certain period of time? Can we be sure people will use architecture for fulfilling these needs in future? The popular formulation of the mission of architecture "to satisfy the utilitarian and aesthetical human needs" would look at least questionable in this case. The dominating today undestanding of the mission and content of architectural activity would become the problem.

This is the reason pushing to search for the answer to the question "How long the aesthetical attitude towards environment exists?"

\section{Methodology of research and materials}

An opinion on the age of aesthetic perception of environment is clearly declared in the some talks ofarchitects. The concept of that phenomenon is "visible" also in other details of contemporary culture, for example - in traditional formulations of the tittles of books and the traditional talking about aesthetics in them. These things are sources, allowing "capture" the dominating opinionabout the age of aesthetics in the contemporarry architectural culture.

The historian's description of the lifestyles concepts of the world structure, values and roles of it's elements (role of men, first of all), lyfe "scenarious", also direct talks in ancient texts about beauty, perception of it, about satisfaction, art e.t.c. are analysed to understand, how the people accepted the most important things that today are associated with category "aesthetics".

After getting the understandings of the age of aesthetics in the both fields (architecture and historical data) are analysed, presented and compared in the article.

\section{Discussions and results}

The concept of age of aesthetical attitude towards environment, existing in the popular architectural culture

There is a widely-accepted viewpoint in contemporary architectural culture that aesthetic intention came into existence along with man and has accompanied him until now.

There are claims that this is the case. For instance, renowned 20th-century architect and theorist A. Rossi states in his book The Architecture of the City: "As the first men-built houses to provide favorable surroundings for their life, so they built with aesthetic intention (underlined by E.S.). Architecture came into being along with the first traces of the city; it is deeply rooted in the formation 
of civilization and is a permanent (underlined by E. S.), universal, and necessary artifact. Aesthetic intention and the creation of better surroundings for life are the two permanent characteristics of architecture" [12].

There is also indirect evidence of existence of such opinion. Today we have many books, named as "Histories of Architecture". Because architecture today is defined as activity, that meets practical and aesthetical tasks, the readers can easily make the conclusion that these aesthetic tasks have appeared in that deep past.

Let's take a look also at what is very close to architecture. Nowadays it is not uncommon to see books named as "Art Histories" in which the human products from the Paleolithic period are presented $[4 ; 5 ; 15]$.

Now art is inseparable from aesthetics. If you think of art as having existed from so ancient times, then, seeing such titles, you can come to conclusion, that an aesthetic relationship between people and their surroundings is the same old too.

There are not only books about very old art, but also there are books directly on the topic of rather old "Aesthetics": on aesthetics of Ancient Greece, on Aesthetics of Middle Ages, e.t.c. $[6 ; 11]$ If not to have much time to go deep into those and other books, into this topic in general, it is very easy to form an opinion, that already first environment which the ancient people used for living, was formed with an aesthetic intention.

The presented facts force me to concludeto conclude, that the the contemporary architecture culture $^{2}$ sees the aesthetical perception of environment as the very old phenomena - as the element of human life, that exists from the moment, the human human beings began to build their first homes.

\section{What does historical data say about the age of an aesthetic attitude towards environment?}

It would be irrational to continue to use the word "aesthetic" without clear definition of the word, solving the next task of this research - trying to figure out, what the historical facts say about the age of the aesthetic attitude of the human being towards the environment.

According to encyclopedias "Aesthetics" today is accepted as rather mysterious phenomenon, still any set of associations of that category with

\footnotetext{
${ }^{I}$ You need to add one thing to what is said. Is falling to the eye, that the words "Aesthetics", "aesthetic" is used rather freely. Having in mind the possible variety of meanings that can be given to the word "Aesthetics", it is correct to state the only thing: this word is used rather often when talking about the very old human past. However, it must be admitted that not always we can know, what about the authors speak exactly.
}

other specific phenomena today is unavoidable. (1) "Aesthetics" is accepted today as something impractical. (2) "Aesthetics" is accepted as something associated with man's feelings. It is tightly tied with (3) beauty and (4) art [13; 3]. This set I seeshould be seenas the essence of the contemporary concept of Aesthetics: if not that set of associations, "Aesthetics" would be nothing today.

To answer the question, what the historical data say about the age of an aesthetical attitude, in my opinion, means to answer the question, what does history tell us about the period of the aforementioned issues. Did man see both sides - that is, practical and impractical in the formation of his surroundings since his very existence? Were the meanings of words "Aesthetics" and "Beauty" always so closely interconnected as they are now? Did the people always treat creative works as one of the principal means of realizing human aesthetic needs, as an instrument of creating "Beauty?" Did the people always associate aesthetic needs with human feelings? Did the people always regard a man as an addressee of art? - in other words, did his creations always have to satisfy his needs?

Below we want to look at what history data speak of the formation of the man's worldview and examine how he may have answered the abovementioned questions in different epochs.

\section{The peculiarities of perception of surroundings in Stone Age}

According to the researcher of the evolution of human thinking O. Freidenberg, "Primitive mentality has three peculiarities. It is concrete, nondifferentiated, and picture-related." [17, 19]. Let us interest about these three features a little more detail.

The insignificance of differentiating the image of the world is noticeable in many spheres of ancient life. According to O. Freidenberg, the primitive consciousness does not distinguish between animate and inanimate, subject and object, between the old and the new. The human features are not perceived all mankind is represented by the external world. The external world is represented in the form of human beings [17,25]. To sum it up, in the primordial worldpictureone object is also another object, in other words, "all equalizes all." $[17,20$ 63].

Absence of one difference is especially interesting for us: there is no such point as a cause in a primitive system of world concept [17, 20]. Not being aware of the existence of causality, a primeval man did not "pose any questions to the nature or seek to answer them" $[17,21]$. He did not value anything. "One is to realize that neither an epithet nor a descriptive name - semantically 
referring to the era of myth-making - expresses any qualitative properties, either bad or good." [17, 53].

Such mentality is visible in all spheres of the life, in primordial formation of environment - too. The earlier the historic period is - the less different from each other the forms of man's-built constructions are. Moving from the Paleolithic to the Neolithic, the man gradually stopped to live in caves and began to construct buildings. He used only one - the oval form building plan. He did so in all cases $[1 ; 8]$.

He did so, building the functionally different (looking from contemporary positions) buildings. $\mathrm{He}$ did so also in all instances of time. Obviously, for one reason or another reason (wandering life, natural disasters, neighboring tribal attacks, etc.) ancient people would reconstruct the buildings; however, they did not change the form of the buildings' plan: a plan for the first buildings (at the Paleolithic-Neolithic juncture) notwithstanding the purpose they served - was oval. And the buildings of a different plan form have not been built for about four thousand years.

These characteristics of primordial mode of activity make us reflect upon: 1) If a primeval man incorporated all his activities into homogeneous forms, then we can presuppose that for him those activities differed little one from another. 2) If, in the case of reconstructing the buildings, he always built them in one form, then he must had accepted that form as a suitable one.

Hence primitive mentality is non-differentiated; besides, one should add that a primeval man could not generalize, abstract: primitive mentality is straightforward and pictorial [17]. Here dominates one mental image. In the totem world outlook, it is dealt with searching for food that is, for an animal, fighting with it, killing it, eating, and worshiping it. Probably because it was all that a primeval man could perceive, historians treat the primeval man's perceived activity as "cosmogony".

Such is mythological mentality. It encompasses the earlier period, which is called the age of "totems" (when an animal was predominating in the image of "everything" and "anything"), and the later period (which is complemented by a subject of reproduction in the image of "everything" and "anything").

Now let us try to answer the question "could the present-day notion of "Aesthetics" (the set of the above-mentioned associations - as something as something associated with man's feelings, as something good, as something impractical, e.t.c.) have been incorporated into such world outlook?" No, it could not. Solely because of the fact that man could not see himself (i.e. he did not discern himself from the animal, tribe or nature in general); that is, he could not live thinking that he was satisfying his unique (human) needs. He could not understand that in existence one can recognize certain needs and their satisfaction. Improper (for men) form of environment did not exist in the primordial mentality: either a primeval man did not concentrate his attention on its quality or he created it thinking not about its quality but something else.

\section{On the human attitude towards the environment in concepts of later époques}

In the course of activity (lasting several thousands of years) the man's ability to separate more clearly the image of the world has developed. It (especially the ability to distinguish details from totality) created preconditions for the development of abstract thinking (generalizations, removed from specific examples or facts). Historians state that in turn it was a precondition for the next changes in the worldpicture - for distinguishing the causes from the consequencesof various phenomena [20].

One starts to notice the existence of cause and effect relationship, but not immediately in the same way as we see it now. During Antiquity and the Middle ages people thought that the cause of everything lied in the will of Gods (later - God). In essence, they (the Gods) become the most powerful ones being resurged through death. With such kind of life "drama" transformations, (human) life is to play a secondary role. A human person in that image of the world is neither a central figure nor a consumer of life. And such distribution of meanings is growing stronger. Several hundred years ago (let us say in the Middle Ages), if one had heard that architecture must meet human needs, he would be resolutely opposed, saying that if it is to meet certain needs, then they are certainly not human, but God ones. In the Middle Ages, all human needs were ignored - practical and impractical ones, as well as his feelings.

Both in Antiquity and in the Middle Ages the letterings "Beauty" and "Art" - nowadays closely interlaced with aesthetical needs - were used; however, they had entirely different meanings. If to take "Beauty", historians state that one can identify three versions of "Beauty" in the Middle Ages.

The first one deals with the continuation of Plato's conception of "Beauty". According to it, "Beauty" lies within God's work. Historians state that "the authors of the Middle Ages would constantly speak of the "Beauty" of the whole existence (underlined by E. S.). Although the history of this epoch is full of obscurantism and contradictions, an image of the universe which the (medieval) theorists in their works depicted, is always covered with enlightenment and optimism." $[6,32]$. 
Here we must come up with an idea: if a medieval man could have envisaged "Beauty" in God's creation, that is, not in things created by men (as it happens today). Let us move along the second conception of beauty in the Middle Ages.

Referring to the second version of understanding of "Beauty" in the Middle Ages, "Beauty" is God Himself (directly) [6, 38, 39, 40; 16]; furthermore, it is the only one. There is no other "Beauty" than this one. U. Eco in one of his books gives such fragment from the medieval texts: "God is called good, for $\mathrm{He}$ breathes life into everything and provides corresponding goodness, enhances and develops it; $\mathrm{He}$ is called beautiful, for He creates the harmony of identity with Himself in all things, together and separately" $[6,38,39,40]$. Alcuin of York (an English scholar, clergy, poet and teacher) and other medieval thinkers call God an "eternal beauty, tenderness, and happiness" $[6,131]$. In the margin, we could write the same remark as in the first version of the concept of beauty: if beauty is God, then it is not the works of man (not that, what we today call "art").

The third medieval version of the concept of "Beauty" is probably the closest to today's concept of "Beauty". Some medieval people could see "Beauty" in those things in which it is most often visible today, that is, in beautiful creatures, in pleasant smells, in soft sounds. But not all people saw it in this way. Those who did so, were faced with a huge challenge: how to justify such "Beauty". Those who acknowledged its existence thought that to admire beautiful creatures, pleasant smells and sounds would only be possible on the condition that they enjoyed these things in order to love God even more (not satisfy any human need).

The position of "Art" in the medieval life drama had to correspond to the same understanding of the world. If $\mathrm{God}$ or His work was regarded as "Beauty", then there was no human activity (whatever we would call it) that may have been treated as the creation of that "Beauty". The notions of "Beauty" and "Art" had nothing in common. The word "Art" was used to denote a masterly accomplished work and name its produce [14]. Referring to medieval "Art, "historians state that "Ars" (now it is translated as "art") was a broad notion embracing those areas which we could name today as craftsmanship or technique. At that time the theory of "Art" was primarily perceived as the theory of mastership" $[6,150,151]$. In the Middle Ages, according to Umberto Eco "/../ one would hardly comprehend what was specifically artistic. The Middle Ages "lacked /../ the conception of art in today's understanding when art is perceived as the creation of things whose prime objective is to evoke an aesthetic gratification, enfolding with sublimity that is endowed by such purpose" $[6,155]$.
The division of phenomena into practical and non-practical ones was difficult task in the Middle Ages. We say "phenomena" but not human needs, because, as it has already been mentioned, human needs were regarded as worthless or even reprehensible.Medieval theorists, according to U. Eco, tried to distinguish what is beautiful and what is beneficial, "Beauty" and "Goodness;" yet, they found it difficult to realize $[6,30]$. If God is considered "Beauty", then it is really hard to determine whether $\mathrm{He}$ pleases us aesthetically or He is practical and not sinful. In general, no matter how He can be classified. Dionysius the Areopagite defines divinity as follows: "/../ the brightest and lightest nebula of silence /../ the brightest of the translucent darkness," which is "neither a body nor a figure nor a form; it has no quantity or quality or weight; /../ it is neither a being nor eternity nor time /../ it is neither darkness nor light; it is neither an error nor the truth." $[6,87]$.

If "Beauty" is considered not as God himself, buo as as God's creation - the universe, the problem of setting it as practical or not, is more or less similar: it makes it difficult to discern what is practical and what is impractical.

The human feelings - how they were seen in Middle Ages?

Historians say that the Middle Ages were a period of extremely hectic experiences. But the medieval man divided the feelings into types and treated them differently. The feling of pleasure was most often considered negatively. See when he came up with the aforementioned medievalconcepts of beauty.

1) Moralists and ascetics believed that the greatest good was to relinquish one's "earthly" feelings $[6,16]$.

2) The concept of the "Beauty"as beauty of the Gods creation (universe), or the beauty of the God himself accepted feelings, however these were not experiences when thinking of yourself as a free and autonomous being and considering your feelings. "There was not a single medieval author who would not have elaborated upon the world's polyphony, and often just along with temperate, precise, and philosophical descriptions ...rapturous infatuation /../" $[6,34]$.

U. Eco gives the fragment of medieval text, illustrating such cases: "When reflecting upon the beauty of the universe /../ it will appear to you /../ that this universe is as if it were the most beautiful song /../" $[6,34]$.

3) Only the third variant of the interpretation of the Holy Bible saw and recognized the human reaction to more usual environment, the right to admire what radiates, sounds pleasant on the ear, and smells sweet. But that was also not the right to enjoy the pleasure of oneself. This was justified only 
in one case - if it was the form (the way) of love toward God. Deriving pleasure from refulgence, pleasant sounds and delicious smell was acceptable only as a means of faith.

We can think that ignoring one's emotional experiences while observing the works of people must have hindered the development of the emotional interpretation of environment in general. The medieval man's sensuous experiences which he did not allow himself to undergo must have become stagnant. The historical facts confirm this. Historian Johann Huizinga writes that the ability to perceive and express in words an aesthetic pleasure (of usual for nowadays environment, works of art) emerges relatively late. A man of the fifteenth century was able to express his admiration for a work of art only in general phrases [9].

\section{The emergence of a modern approach to the environment}

The more abstractly God was observed, the more questions were raised in relation to his nature. In the eighteenth century, it seems to have been fundamentally examined. The existence of God casts some considerable doubt in Western world in general [2]. The image of God begins to blur. The former content of the notion of "Beauty" vanishes: if there is no God, then there is not beauty in the form of himself or his creation. Belief in the existence of God weakens, but there is no emptiness - it transforms into belief into the laws of the world and into the ability of man to discover them [19]. Man starts to view himself as a central figure in the drama of life - not only as a revealer of its secrets but also as their user.

In the mid of the eighteenth century, A. Baumgarten's proposal to pay more attention to what is related to human feelings (and it is what he suggests calling "Aesthetics" and linking it with "Beauty") [7] appears to be very timely. Some decades later, Immanuel Kant endows human feelings with a new high importance [10]. He distinguishes unequivocally what is a practical and impractical human relationship with the surroundings and defines the latter one as "Aesthetics" (which is inextricably interwoven with the contemporary concept of "Beauty"). The category of "Beauty" (now associated with the category of "Aesthetics") has a new content. It is a degree of satisfying man's impractical needs.

The concept of a human "Aesthetic" relationship with the surroundings assumes all the main features inherent to that of today: one turns satisfaction of the needs in the meaning of human life and identifies both what is practical and impractical in these needs; the concepts of "Aesthetics" and "Beauty" become very close in essence; and "Art" becomes considered as one of the crucial means of realizing "Aesthetic" needs, as an instrument of creating "Beauty."

\section{Conclusions}

In the case "Aesthetics" is accepted as the set of nowadays wel known associations (as something impractical, as something associated with man's feelings and tightly tied with beauty and art) the popular in the contemporary architectural culture thought, that an aesthetic attitude of the human being towards its environment exists from the times, when the first men built houses, contradicts the historical data. This data show that the people started to interest in their feelings, to accept this interest as not practical one, to connect it with beauty and relate the satisfaction of it with the human artistic activity relatively not so long ago.

The historical data puts the modern concept of architecture into a complicated situation. If we want to consider architecture as an aesthetic activity, it should be necessary to refuse to call as architecture the construction activity roughly to the XVIII century. If anybody had the wish to leavename "Architecture" for calling construction activity up to this time, it should refuse to define architecture as the aesthetical activity - activity, fulfilling the practical and aesthetical human needs.

The historical lessons raise also such question: is it not to courageous to define the formation of an environment as aesthetic activity, not knowing how long the contemporary way of the human approach towards environment will last.

Such thoughts place architectural theory and the way of practical life in to dramatic (but interesting) situation: we should recognize that the „foothold“ of contemporarry mode of architecture - popular formulation of the mission of architecture "to satisfy the utilitarian and aesthetical human needs" is probably not correct.

Of course, the question "how the mission of architecture should be formulated correctly?" appears immediately. Still it is not necessary to hurry to answer the question. Fast and simple additions to the popular definition of architecture here can be not enough and may be even dangerous. The presented material displays the necessity of deeper rethinking of the popular concept of the mission of architecture.

However, the necessity of one change in the "construction" of contemporary concept of architectural life seems clear already now: architectural culture should not close it selfonly into the looking to the form of environment. Not only the form of environment should be accepted as the object of architectural activity. Our way of life (also our understanding of essence of architecture) - is not less interesting and topical thing. 


\section{References}

1. Banning, E. B. The Neolithic Period: Triumphs of Architecture, Agriculture, and Art. Near Eastern Archaeology, 1998, Vol. 61 (4), p. 188-237.

2. The Cambridge History of Christianity. Vol. VII: Enlightenment, Reawakening and Revolution 1660-1815. Brown, S. J., Tackett T. (eds.). New York: Cambridge University Press, 2008. [Available also at:] http://ebooks.rahnuma.org/religion/Christianity/The_Cambridge_History_of_Christianity_Volume_7_Revolution_16 60-1815_.pdf

3. Aesthetics: A Comprehensive Anthology. Cahn S. M, Meskin A. (eds.) Malden, MA: Wiley-Blackwell publishing, 2007. $704 \mathrm{p}$.

4. Clottes, J. What Is Paleolithic Art? Cave paintings and the Dawn of Human Creativity. Chicago: The University of Chicago press, 2016. 208 p.

5. Dale Guthrie, R. The Nature of Paleolithic Art. Chicago: The University of Chicago Press, 2005. 520 p

6. Eco, U. Menas ir grožis viduramžiu estetikoje. Vilnius: Baltoslankos, 1997. 251 p.

7. Guyer, P. Values of Beauty - Historical Essays in Aesthetics. Cambridge: Cambridge University Press, 2005. 382 p.

8. Bar-Yosef, O. The Natufian Culture in the Levant, Threshold to the Origins of Agriculture. Evolutionary Anthropology Issues News and Reviews, 1998, Vol. 6 (5), p. 159-177.

9. Huizinga, J. The waning of the Middle Ages.London: Penguin, 1992, p. 266-274

10. Kant, I. Critique of the power of judgment. The Cambridge Edition of the Works of Immanuel Kant. Cambridge: Cambridge University Press, 2001. 476 p.

11. Porter, J. I. The Origins of Aesthetic Thought in Ancient Greece: Matter, Sensation, and Experience. 1sd ed. Cambridge, Cambridge University Press, 2010.626 p.

12. Rossi, A. The Architecture of the City.Cambridge, Massachusetts, London: MIT Press, 1982, p. 21.

13. Scruton, R., Munro, T. Aesthetics [online] Encyclopaedia Britanica [cited 16.07.2018]. http://www.britannica. com/topic/aesthetics

14. Tatarkievicz, W. Šešių sąvokų istorija. Vilnius: Vaga, 2007. 487 p.

15. Thomas, A. Art and Architecture in Neolithic Orkney. Oxford: Archaeopress Publishing, 2016. 274 p.

16. Verdon, J. Viduramžiu malonumai. Vilnius: Baltos lankos, 2000. 175 p.

17. Фрейденберг, О. М. Миф и литература древности. Москва: Наука, 1978. 605 p

18. Пригожин, И., Стенгерс, И. Порядок из хаоса. Новый диалог человека с природой. Москва: Прогресс, 1986. 432 p.

19. Столяр, А. Д. Происхождение изобразительного искусства. Москва: Искусство, 1985, 300 p.

INFORMATION ABOUT THE AUTHOR:

Eugenijus Staniunas - Dr., associated professor at Vilnius Gediminas Technical University, department of Urban design; LT - 09125 Vilnius, Žirmūnų 166 - 8; phone: +370 861695206; e.staniunas@gmail.com. Field of interest - culture of Architecture.

Kopsavilkums. Pētījuma objekts ir saskares josla starp diviem „elementiem” - populāro mūsdienu arhitektūras kultūru un datiem par vēstures zināšanām mūsdienās. Izpētē piedāvāts savienot „Estētikas” apziņu, kā tā tiek skatîta abās līnijas pusēs, mēǵinot noskaidrot vai mūsdienu arhitektūras sabiedrība saskata ilglaicību cilvēku estētiskajā attieksmē pret vinu vidi, līdzīgi kā to rāda vēsturiskie dati. 